\title{
The development of the ovine fetal adrenal gland and its regulation
}

\author{
E Naaman Répérant ${ }^{1 *}, \mathrm{P}$ Durand ${ }^{2}$ \\ I PRMD, Inra, 37380 Nouzilly; \\ ${ }^{2}$ Inserm-Inra U418, hôpital Debrousse, 29, rue Scur Bouvier, 69322 Lyon cedex, France
}

(Received 5 July 1996; accepted 23 October 1996)

\begin{abstract}
Summary - In mammalian species, the fetal adrenal gland plays a key role during late gestation since fetal glucocorticoids are involved in the maturation of the fetus and in the adaptation of the neonate to extra-uterine life. Moreover, in domestic ruminants as well as in the pig, the onset of parturition is triggered by an increased level of fetal plasma glucocorticoids. This prepartum rise of fetal glucocorticoids, which conveys growth and differentiation of adrenocortical cells, is not only under pituitary control but also involves local regulations. We review the actual knowledge of the modalities of fetal adrenal development in the sheep and its regulation by the adrenocorticotropic hormone (ACTH) and other factors.
\end{abstract}

\section{ovine fetal adrenal / maturation / regulation}

Résumé - Développement de la glande surrénale foetale ovine et sa régulation. Chez les mammifères, les glandes surrénales du fœtus jouent un rôle essentiel en fin de gestation étant donné que les glucocorticoïdes fœtaux sont impliqués dans la maturation du fœtus et dans l'adaptation du nouveau-né à la vie extra-utérine. En outre, chez les ruminants domestiques de même que chez le porc, l'augmentation des glucocorticoïdes fœtaux en fin de gestation déclenche la parturition. Cette augmentation prépartum des glucocorticoïdes fœetaux, qui traduit la croissance et la différenciation des cellules corticosurrénaliennes fœtales, n'est pas seulement sous contrôle hypophysaire mais implique également des régulations locales. Nous nous proposons de faire le point des connaissances actuelles sur les modalités du développement de la surrénale fœtale ovine et sa régulation par l'ACTH et d'autres facteurs.

\section{surrénale fuetale ovine / développement / régulation}

* Correspondence and reprints

Tel: (33) 02474277 84; fax: (33) 02474277 43; e-mail: naaman@tours.inra.fr 


\section{INTRODUCTION}

In mammalian species, the fetal adrenal gland plays a key role during the last third of gestation since glucocorticoids are involved in the maturation of many fetal organ systems (Liggins, 1976, 1994). Moreover, in domestic ruminants as well as in the pig, the onset of parturition is triggered by an increased level of fetal plasma glucocorticoids (Nathanielsz, 1978; Challis and Lye, 1986). In the sheep, this increase occurs from about 120 days of gestation (G120) onwards and results from an enhanced activity of the fetal adrenal cortex (Alexander et al, 1968; Brown et al, 1978). This enhanced activity is in turn due to both an increase in trophic stimulation of the gland by the adrenocorticotropic hormone (ACTH) and to an important development of the ability of fetal adrenal cells to produce steroids (for review, see Durand, 1987). This latter development is mainly related to modifications involving both ACTH-sensitive adenylate cyclase system and some steps of the steroidogenic pathway (for review, see Durand, 1992). However, the mechanisms involved in the growth and differentiation of the fetal adrenal cortex are not fully elucidated. In this report, the growth and maturation processes involved in the development of the fetal adrenal cortex and their regulation by ACTH and other factors will be reviewed.

\section{STRUCTURE AND GROWTH OF THE ADRENAL CORTEX}

In adult mammalian species, the adrenal gland is divided into two regions of different origins. The inner part of the adrenal gland is of ectodermic origin and produces various peptides and catecholamines. The external region, or adrenal cortex, is of mesodermic origin and includes three parts: the zona glomerulosa, the zona fasciculata and the zona reticularis. These produce mineralocorticoids, glucocor- ticoids and adrenal androgens, respectively (Long, 1975).

In the ovine fetus (length of gestation: 145-150 days), the adrenal gland can be identified as early as G28 (Wintour et al, 1975) but its zonation becomes apparent at G60 (Webb, 1980). The outer zone seems to be the equivalent of the adult zona glomerulosa, whereas the inner zone corresponds to the zona fasciculata (Robinson et al, 1979; Webb, 1980). Zona reticularis only becomes apparent in the 1-month-old lamb. However, even in the adult sheep, androgen production is low.

Fetal adrenal glands grow in a biphasic manner. During the first growth (ie, period of rapid growth), between G60 and G120, zona glomerulosa develops; however, already at G60, zona glomerulosa cells seem able to produce corticosteroids. The second growth period, which occurs just before birth, corresponds essentially to the development and maturation of the zona fasciculata (Webb, 1980; Boshier and Holloway, 1989). During this period, the adrenal weight doubles and reaches $300 \mathrm{mg}$ (Durand et al, 1978).

Mechanisms responsible for this adrenal growth are not fully elucidated. However, when the fetus is hypophysectomized during the last month of gestation, there is no weight increase of the adrenals. Conversely, ACTH infusion to 115-day-old fetuses leads to an anticipated growth of the adrenal cortical zone (Liggins et al, 1973; Durand et al, 1980). Recent experiments have also shown that chronic administration of ACTH to hypophysectomized fetal sheep leads to normal term labor, preventing the effect of hypophysectomy (Jacobs et al, 1994). These results show the essential role of ACTH in ovine fetal adrenal growth and maturation. Physiologically, however, the second period of fetal adrenal growth cannot be directly related to a significant increase in the levels of immunoreactive ACTH present in the fetal blood (see later). Factors other than ACTH might also be involved in the growth of the sheep fetal 
adrenal gland. Thus, the fibroblast growth factor (FGF) (Gospodarowicz et al, 1977), and to a lesser extent angiotensin II (A-II) (Hornsby and Gill, 1977), exert a mitogenic effect on adult adrenocortical cells in vitro. Moreover, various pro-opiomelanocortine (POMC)-derived peptides were shown to stimulate DNA synthesis in adult rat adrenocortical cells in culture and to increase the adrenal mitotic index in vivo (Estivariz et al, 1982). However, the action of these factors remains unknown in fetal adrenal cells. In the ovine fetus, the epidermal growth factor (EGF) injection stimulates the growth of various endocrine glands such as the adrenal, without increasing corticosteroid output (Sundell et al, 1975). More recent experiments have shown that insulin and particularly insulin-like growth factor I (IGF-I) are able to induce proliferation of fetal ovine adrenocortical cells cultured in a chemically defined medium (Naaman et al, 1989). In addition, it is now clear that many fetal tissues, including the adrenal cortex, are able to produce growth factors. Indeed, sheep fetal adrenal cortices synthesize transforming growth factor $\beta 1$ (TGF $\beta 1$ ), IGF-I and IGF-II (mRNAs and peptides) (Han et al, 1992; Naaman-Répérant et al, 1996). Taken together, these results suggest that fetal adrenal growth could be controlled by a set of factors of endocrine and/or paracrine origin which can vary according to the stage of development.

\section{FETAL PLASMA LEVELS OF CORTICOSTEROIDS}

In the ovine fetus, the levels of plasma corticosteroids remain stable between $\mathrm{G100}$ and G125 (5-10 ng/mL). They then increase progressively up to G140 to enhance dramati-
Fig 1. Plasma corticosteroid concentrations ovine fetuses and number of adrenocorticotropic hormone $(\mathrm{ACTH})$ receptors $(\mathrm{O}-\mathrm{O})$ per two adrenals of the same fetuses. The number of animals is indicated in parentheses (Durand, 1979).

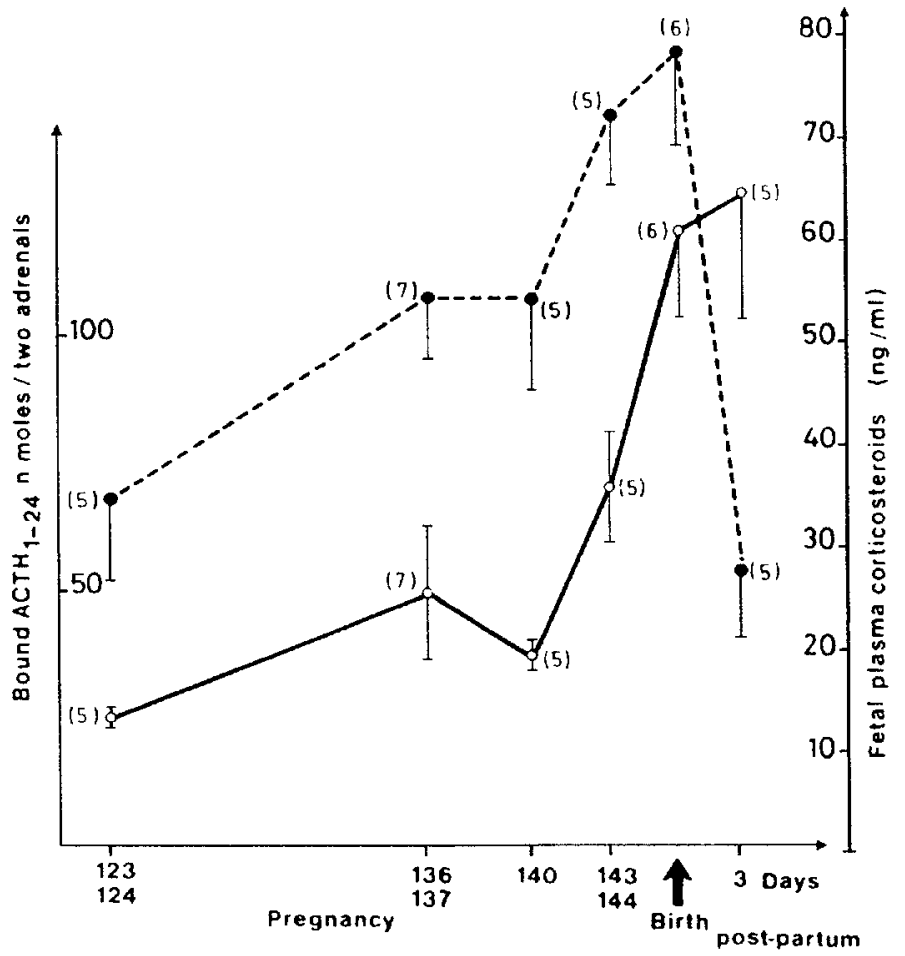


cally just before birth when they can reach $100 \mathrm{ng} / \mathrm{mL}$ (see fig 1). In the newborn lamb, they decrease within a few days to levels similar to those found in the adult (around 4 $\mathrm{ng} / \mathrm{mL}$ ) (Alexander et al, 1968; Brown et al, 1978; Magyar et al, 1980). From G100 on, fetal ovine plasma contains aldosterone, corticosterone, cortisol, 11-deoxycortisol and 11deoxycorticosterone (Wintour et al, 1975; Thomas et al, 1976; Brown et al, 1978). Before G120, however, plasma corticosteroids are essentially from maternal origin, since plasma levels of corticosterone and cortisol are similar in normal and adrenalectomized fetuses (Hennessy et al, 1982). It is only from G120 onwards that the fetus starts producing cortisol (Wintour et al, 1980). Corticosterone and cortisol represent $90 \%$ of plasma corticosteroids (Jones et al, 1977). In vitro, fetal adrenal cells (G113) produce mainly 11deoxycorticosterone and corticosterone and lower amounts of $17 \alpha$-hydroxylated steroids, 11-deoxycortisol and cortisol (Cathiard et al, 1985). The cortisol/corticosterone ratio varies throughout gestation (Thomas et al, 1976; Brown et al, 1978). Many in vivo studies have shown that the pre-term increase in corticosteroids is mainly due to an enhanced secretion of cortisol. Durand et al (1981a) have also shown, in vitro, a progressive increase of cortisol/corticosterone during late gestation in the incubation medium of dissociated fetal adrenal cells. These results indicate a late development of $17 \alpha$-hydroxylase activity (P450-C17) (Thomas et al, 1976; Brown et al, 1978; Wintour et al, 1995).

\section{SECRETION AND EFFECT OF ACTH IN THE OVINE FETUS}

The presence of ACTH can be detected as soon as $\mathrm{G} 40$ and $\mathrm{G} 60$, respectively, in the anterior and intermediary lobes of the ovine fetal pituitary (Mulvogue et al, 1986). At G90, two morphologically distinct types of corticotropic cells, a fetal and an adult type, can be observed (Antolovich et al, 1989). As gesta- tion proceeds, the fetal type cells decrease in number to disappear in the adult animal, whereas the adult type cells increase from G130 on to become predominant around G140.

Immunoreactive ACTH plasma levels seem constant between G100 and G140 and increase only in the last days preceding parturition, just after the increase of cortisol (Rees et al, 1975; Challis et al, 1977; Jones et al, 1977; Durand et al, 1980; Wintour et al, 1980). Such results are to be considered carefully because ACTH levels vary throughout the day and are influenced by the stress of the animal. Moreover, ACTH is secreted episodically in the fetus (Nathanielsz et al, 1977; Jones, 1979), and ACTH plasma levels may not be representative if only a single blood sample is taken daily. Furthermore, immunoreactive ACTH does not correspond to bioactive ACTH. In fact, there is an important increase (four- to eight-fold) of the biological activity/radioimmunological activity (B/I) ratio of ACTH secreted in vitro by ovine pituitary cells between $\mathrm{G} 63$ and 1 week postpartum (Brieu and Durand, 1987). This observation is most probably due to the existence of various molecular weight forms of ACTH (see later) in addition to the presence of other POMC-derived peptides in the pituitary (and plasma) (for review, see Eipper and Mains, 1980).

Maternal and fetal sheep pituitaries contain melanocyte-stimulating hormone $(\alpha-$ $\mathrm{MSH}$ ), corticotropin-like intermediate peptide (CLIP), $\beta$-MSH, lipotropic hormone ( $\beta$-LPH), $\beta$-endorphin, ACTH1-39 (biologically active) as well as high molecular weight forms of ACTH (Silman et al, 1979; Jones and Robuck, 1980). The ratio of these high molecular weight forms/ACTH1-39 is higher in the fetal than in the adult pituitary (Silman et al, 1979), and ACTH1-39 becomes predominent during the last 2 weeks of gestation (Jones and Robuck, 1980; Carr et al, 1995). Interestingly, the concentration of $\mathrm{ACTH}$ precursors is not changed throughout the last 
third of gestation, whereas ACTH1-39 increases significantly towards term (Carr et al, 1995). Similarly, the proportion of high molecular weight forms of ACTH are lower in the incubation medium of neonatal than fetal pituitary cells (Brieu and Durand, 1989). Therefore, immunoreactive ACTH plasma levels are not representative of the 'adrenocorticotropic activity' present in fetal blood. These variations in biologically active plasma $\mathrm{ACTH}$ are as important as quantitative variations of ACTH in regulating fetal adrenal activity.

Mechanisms controlling ACTH synthesis and regulation during fetal life remain to be fully elucidated. In fact, in vivo studies involving both mother and fetus cannot exclude maternal influence. However, when ovine corticotropin-releasing hormone (oCRH) 141 or arginine vasopressin (AVP) is injected in utero into catheterized fetuses from $\mathrm{G} 110$ to $\mathrm{G} 142$, the fetal ovine pituitary responds to this stimulation by increasing its secretion of ACTH1-39 and precursors (Hargrave and Rose, 1986; Carr et al, 1995). Moreover, at G120, AVP and oCRH produce synergistic increases in ACTH1-39 and precursors whereas the response is only additive at other ages (Carr et al, 1995). In vitro experiments show that already at G63, ovine pituitary cells respond to oCRH1-41 and to AVP and that these responses decrease regularly during the last month of gestation (Durand et al, 1986). This latter result could be explained by a desensitization of fetal pituitary cells to oCRH1-41 and AVP in which outputs are elevated at that period (Brieu et al, 1989) and/or by the increase of plasma levels of corticosteroids observed at this period.

In addition, oCRH1-41 or AVP-stimulated fetal pituitary cells produce more low molecular forms of ACTH than control cells. When 120-day-old ovine fetal pituitary cells are stimulated for 4 days by AVP, the proportion of low molecular weight forms of ACTH is enhanced, leading to an increased biological activity/radioimmunological activ- ity ratio of secreted ACTH (Brieu and Durand, 1987). Therefore, the fetal hypothalamus seems to be involved in the changes in ACTH bioactivity secreted by fetal pituitary cells at late gestation. Recent in vivo experiments have demonstrated the importance of fetal hypothalamus in these regulations. Indeed, bilateral destruction of the ovine fetal paraventricular nuclei leads to decreased oCRH amounts in the external region of the median eminence and thereby prevents prepartum increase of ACTH (McDonald and Nathanielsz, 1991). Between G63 and G138, hypothalamic contents in AVP and CRH increase as well as their biological activity responsible for $\mathrm{ACTH}$ output (Brieu et al, 1989). In addition, the ratio of $A V P / C R H$ hypothalamic contents is around 5 between G63 and G123 and decreases towards late gestation to reach 1, just before parturition (Brieu et al, 1989). Finally, AVP neurons are allready detected in the paraventricular and supraoptic nuclei as soon as G42, whereas CRH is only detected from G90 on (Levidiotis et al, 1987). The co-localization of CRH and AVP in the same neurons could not be observed as in the adult sheep. These data suggest that AVP might play an essential role in regulating $\mathrm{ACTH}$ output in the ovine fetus, particularly before G120. However, factors other than AVP and CRH, especially corticosteroids, also exert an effect on ACTH secretion.

\section{FEEDBACK REGULATIONS BETWEEN CORTICOSTEROIDS AND ACTH}

In the adult animal, circulating corticosteroids inhibit pituitary ACTH output by acting at both hypothalamic and pituitary levels. At the very end of gestation, however, there are high levels of both plasma cortisol and ACTH in the ovine fetus (Rees et al, 1975; Jones et al, 1977; Durand et al, 1980). This observation raises the question of the sensitivity or even the existence of corticosteroid feedback during fetal life. In vivo, increasing 'physiolog- 
1980; Wood and Rudolph, 1983) or blocking corticosteroid production (Durand et al, 1981c) have shown that around G120, the negative feedback mechanism of cortisol on ACTH production is functional in the ovine fetus. In vitro, cortisol and corticosterone used at either $10^{-9}$ or $10^{-7} \mathrm{M}$ inhibit fetal ovine corticotropic cell response to oCRH1-41 between G63 and G144. The efficiency of these steroids is higher at G63 than later on (Durand et al, 1986).

The presence of glucocorticoid receptors was shown both in cytosolic preparations and in intact hypothalamic and pituitary cells from ovine fetuses between G100 and birth (Yang et al, 1990). Interestingly, in both tissues, the number of glucocorticoid receptors was higher at G100 than later on, likely contributing to the greater sensitivity of hypothalamic and pituitary cells to glucocorticoid feedback at this period.

In addition, the levels of corticosteroidbinding globulin ( $\mathrm{CBG}$ ) modulate the bioavailability of cortisol for hypothalamic and pituitary cells. Indeed, basal and CRHinduced ACTH secretion by cultured pituitary cells is inhibited by cortisol and this inhibition is decreased in the presence of CBG. In fact, the prepartum increase of cortisol is associated with an increase in CBG (Ballard et al, 1982). Berdusco et al (1995) confirmed that the lower availability of glucocorticoids at this period was partly due to an increase in both CBG and its capacity to bind corticoids.

Moreover, an increase in the metabolization of corticosteroids at the end of gestation was also proposed. Indeed, the pituitary expression (mRNAs and activity) of $11 \beta$ hydroxysteroid dehydrogenase 1 (11 $\beta$-HSD1), a microsomal enzyme responsible for the interconversion of glucocorticoids and their inactive metabolites, increases dramatically in the pars tuberalis of ovine fetuses at late gestation and after parturition (Yang et al, 1995). This suggests that $11 \beta$-HSD1 could contribute to lower the efficiency of cortisol negative feedback on ACTH secretion during late gestation.

Finally, it was suggested that the 'massive' increase of cortisol just before parturition might reflect a positive feedback of cortisol on the fetal hypothalamo-pituitary-adrenal axis (Nathanielsz et al, 1972; Jones et al, 1978b). Between G133 and G144, cortisol and corticosterone at $10^{-9} \mathrm{M}$ do not inhibit, but enhance AVP-induced ACTH output by pituitary cells in vitro (Durand et al, 1986). In addition, cortisol increases the biological activity/radioimmunological activity ratio of ACTH secreted by 120 -day-old fetal pituitary cells (Brieu and Durand, 1987). Moreover, a 6 day cortisol infusion to 115 -day-old fetuses induces the development of 'adult type' corticotrophs which become predominent compared to 'fetal type' corticotrophs (Antolovich et al, 1991).

\section{FETAL ADRENAL MATURATION: ROLE OF ACTH}

Many studies have shown that ovine fetal adrenal sensitivity to ACTH varies greatly throughout gestation. Ovine fetal adrenal slices or isolated cells secrete in vitro important amounts of cortisol and corticosterone in response to $\mathrm{ACTH}$ around $\mathrm{G} 60$. This adrenal sensitivity to ACTH disappears around G100 to reappear progressively during the last month of gestation and culminate at birth. A similar pattern of adrenal sensitivity is also observed in vivo when increasing endogenous ACTH levels by inducing stresses (through hypoxemia or hemorrage) during the last month of gestation (reviews by Durand et al, 1982b; Saez et al, 1984; Durand, 1987; Challis and Brooks, 1989). The reasons why fetuses are much more responsive to $A C T H$ around $G 60$ than $G 100$ are not fully elucidated.

We have previously seen that ACTH is able to induce fetal adrenal growth (see earlier), even at a stage when the sensitivity of the 


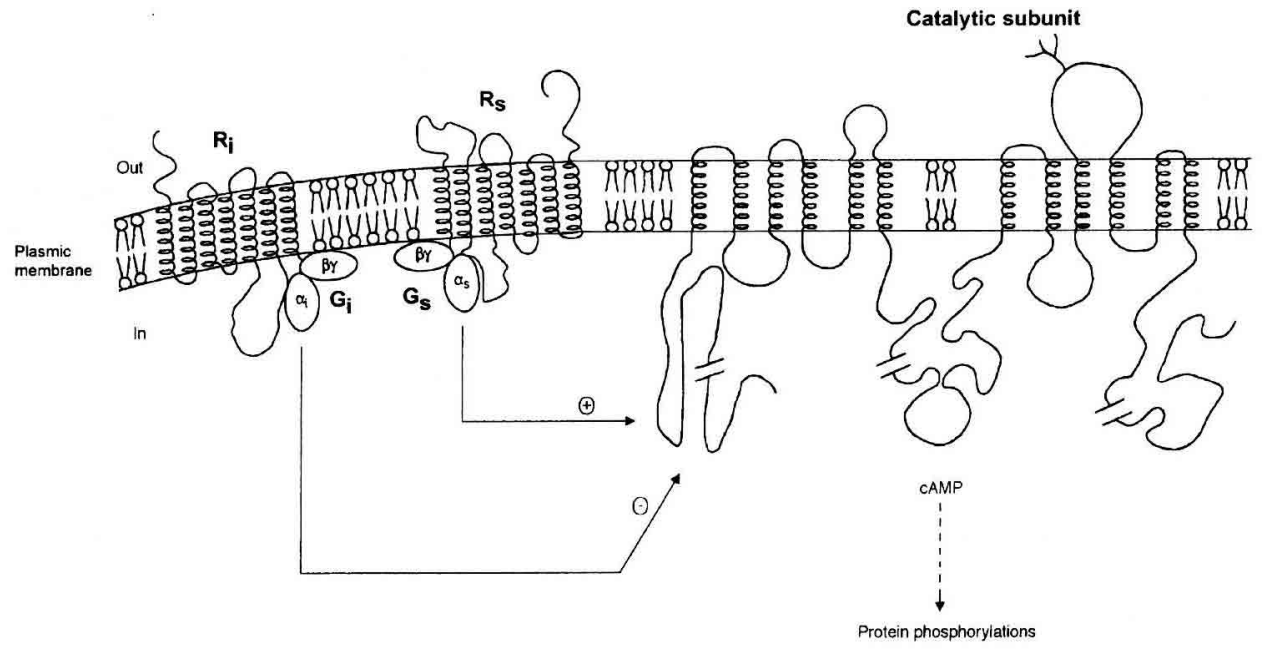

Fig 2. The adrenocorticotropic hormone ( $\mathrm{ACTH}$ )-sensitive adenylate cyclase system, consisting of a guanine stimulatory subunit $\left(\mathrm{G}_{\mathrm{s}}\right)$ and a guanine inhibitory subunit $\left(\mathrm{G}_{\mathrm{i}}\right)$ activated by their corresponding receptors, $R_{s}$ and $R_{i}$, respectively. As indicated in their denomination, $G_{s}$ will stimulate $(+)$ adenylate cyclase activity and consecutively increase cyclic adenosine monophosphate (cAMP) production whereas $\mathrm{G}_{\mathrm{i}}$ will inhibit ( - ) it. $\alpha_{s}, \beta$ and $\gamma$ constitute the $\mathrm{G}_{\mathrm{s}}$ subunits which can be stimulated by either guanosine triphosphate (GTP) or analogs such as Gpp(NH)p or cholera toxin (from Féger and Féger, 1993, after modification).

adrenal to ACTH is low. In fact, in 100-dayold fetuses, ACTH infusion induces premature delivery, and resulting cortisol levels are similar to those observed in normal newborn lambs (Liggins, 1968; Jones et al, 1978a; Cabalum et al, 1982). This fetal adrenal maturation by ACTH implies modifications both in the ACTH-sensitive adenylate cyclase system and in some steps along the steroidogenic pathway.

\section{The ACTH sensitive adenylate cyclase system}

ACTH binds noncovalently to a specific membrane receptor $(R)$, activating the adenylate cyclase $(A C)$ via $G$ proteins $\left(G_{s}\right)$ (for review see Saez et al, 1989). This interaction results in an increased production of cyclic adenosine monophosphate (cAMP), which in turn activates cAMP-dependent kinases
(PKA), subsequently inducing an enhancement of steroidogenesis (fig 2).

The ACTH receptor is part of the receptor family presenting seven transmembrane domains (Cone and Mountjoy, 1993). ACTH is able to regulate the expression of its own receptor in the adult sheep adrenal (PicardHagen et al, 1996).

In ovine fetal adrenal membrane preparations, the number of ACTH-binding sites stable between G120 and G140 increases threefold between G140 and birth (see fig 1), when adrenal sensitivity to ACTH is highest (Durand, 1979). At G120, ACTH alone is not able to increase either $\mathrm{AC}$ activity of membrane preparations (Durand et al, 1981b) or cAMP production by isolated cells (Durand et al, $1981 \mathrm{a}, \mathrm{c})$. However, this activity can be stimulated by ACTH in the presence of guanosine triphosphate (GTP), or analogs such as Gpp(NH)p. Conversely, at G140, although there is no increase in the number of ACTH 
receptors per cell compared to $\mathrm{G} 120, \mathrm{ACTH}$ alone is able to stimulate AC activity (Durand et al, 1985a). Taken together, these results suggest that the insensitivity of AC to ACTH stimulation before G140 is due to a lack of GTP and to a lower activity of $\alpha_{\mathrm{S}}\left(\mathrm{a} \mathrm{G}_{\mathrm{s}}\right.$ subunits) (Durand et al, 1985a). The increased response to ACTH observed between G140 and birth would mainly result from an increased number of ACTH receptors since, during this period, the response to $\mathrm{Gpp}(\mathrm{NH}) \mathrm{p}$ alone remains unchanged (Durand et al, 1984). However, results obtained with isolated adrenal cells show that post-cAMP modifications are also involved in the prepartum maturation of the fetal adrenal gland.

\section{The steroidogenic pathway}

The increased capability of ovine fetal adrenal cells to produce corticosteroids before birth seems mainly related to alterations occurring early in the steroidogenic pathway leading to increased production of pregnenolone (Durand et al, 1984, 1985b). The lower fetal pregnenolone production can be partially related to the fact that intramitochondrial concentrations of free and esterified cholesterol are, respectively, two- and 22-fold lower in fetuses than in newborn lambs. Moreover, 3-hydroxy3-methylglutaryl-Coenzyme A reductase (3HMG-CoA) activity (the limiting step in de novo synthesis of cholesterol) in the fetus is half that of the newborn lamb (NaamanRépérant et al, 1992). However, low levels of cholesterol, although contributing to the lower fetal pregnenolone production, are probably not the principal factor limiting steroidogenesis in these animals. In fact, steroidogenic enzymes involved in corticosteroid synthesis seem to be essentially responsible for the increased steroidogenic capacity of fetal adrenals at late gestation. During the last month of intra-uterine life, there is an increase in P450 side-chain cleavage ( $\mathrm{P} 450 \mathrm{scc}$ ), $3 \beta$ hydroxysteroid dehydrogenase isomerase $(3 \beta$ HSD) and P450-C17 activities, and to a lesser extent of 21 - and $11 \beta$-hydroxylase (P450C11) activities (Durand et al, 1982b; Naaman-Répérant et al, 1992). Similarly, the amounts of P450scc, P450-C17 and P450C21 encoding mRNAs increase at late gestation (Tangalakis et al, 1989).

ACTH-induced cAMP production exerts both short-term (or acute) and long-term (or chronic) effects on adrenal steroidogenesis. Short-term effects occur within minutes following ACTH binding to its receptor and concern cholesterol mobilization and transport to P450scc. Long-term effects occur within a few hours and concern the expression of some steroidogenic enzyme encoding genes.

In vivo $\mathrm{ACTH}$ infusion to the fetus around G110 results in an increased pregnenolone production by isolated cells in response to ACTH, similar to the one observed in newborn lambs (Durand et al, 1982a). Moreover, ACTH infusion was shown to stimulate the expression of $\mathrm{P} 450 \mathrm{scc}$ and $\mathrm{P} 450-\mathrm{C} 17$ encoding mRNAs. This effect of ACTH required at least 6-12 h to occur and could be reversed by stopping ACTH treatment (Tangalakis et al, 1990, 1992). However, since ACTH is not able to increase $\mathrm{P} 450 \mathrm{scc}$ activity and protein amount in vitro (our unpublished observations), although increasing the corresponding mRNAs, factors other than ACTH should also be involved in the development of fetal adrenal steroidogenesis.

\section{THE ROLE OF OTHER FACTORS ON FETAL ADRENAL STEROIDOGENE- SIS}

Several factors have been identified for modulating fetal adrenal steroidogenesis such as prostaglandin $\mathrm{E}_{2}\left(\mathrm{PGE}_{2}\right)$, POMC-derived peptides, naloxone, EGF and growth hormone (GH). However, the precise role of these factors remains to be explained and most of the observations made in vivo could not be reproduced in vitro (review by Durand, 1987). More recent in vitro experiments have shown 
that adrenal steroidogenesis can be regulated not only by hormones such as ACTH, A-II and glucocorticoids, but also by other peptides such as growth factors like IGF-I and TGF $\beta 1$ (for review, see Feige and Baird, 1991). All these factors exert endocrine and/or auto/paracrine effects which modulate fetal adrenal growth and differentiation.

\section{Positive effects}

\section{Role of fetal glucocorticoids}

The existence of glucocorticoid receptors in the adrenal supports the hypothetical auto/paracrine role of glucocorticoids in this gland (Loose et al, 1980).

It has been shown that in both fetal and adult ovine adrenal cells in culture, low concentrations of glucocorticoids $\left(\mathrm{ED}_{50}=10^{-8}\right.$ $\mathrm{M}$ for dexamethasone) increase cAMP and corticosteroid productions in response to ACTH, whereas aminogluthetimide, a $\mathrm{P} 450 \mathrm{scc}$ inhibitor, decreases cAMP productions (Darbeida and Durand, 1987; Darbeida et al, 1987).

Glucocorticoids exert a specific effect on the number of ACTH receptors without modifying G subunits (Darbeida and Durand, 1990). This increased number of ACTH receptors by glucocorticoids is related to an enhanced transcription of the corresponding mRNAs (Picard-Hagen et al, 1996). The increased number of ACTH receptors in response to ACTH could therefore be partly mediated by glucocorticoids. Glucocorticoids also enhance pregnenolone production by cultured adrenal cells (Picard-Hagen et al, 1995), thus increasing the pool of intramitochondrial cholesterol as well as mitochondrial ability to synthesize pregnenolone. However, glucocorticoids have no effect on steroidogenic enzymes since they do not increase corticosterone production by adrenal cells incubated with pregnenolone in excess. Taken together, these results suggest that glucocorticoids are involved in the maturation of the fetal ovine adrenal gland. Considering the auto-amplifying effect of glucocorticoids on their own synthesis, they could probably contribute to explain the drastic increase of fetal plasma glucocorticoid levels observed just before parturition.

\section{Effect of IGF-I}

The effect of IGF-I on fetal development is exerted both on cell proliferation and differentiation (for review, see Sara and Hall, 1990). Its effect is mediated through IGF receptors of type I which are responsible for 'somatomedin-like actions'. IGF-I was shown to stimulate growth and differentiation of ovine fetal adrenal cells in culture, in the presence or absence of ACTH (Naaman et al, 1989). Nanomolar concentrations of insulin or IGF-I increase ACTH-induced cAMP production by 120-day-old fetal adrenal cells and to a lesser extent, cholera toxin-induced cAMP production. Knowing that in bovine adrenal cells, IGF-I increases mainly the number of ACTH receptors (Penhoat et al, 1989), and to a lesser extent $\mathrm{G}_{\mathrm{S}}$ subunits (Bégeot et al, 1991), insulin and IGF-I are most probably involved in the maintenance and/or the development of the adrenal AC system. IGF-I is also able to increase 8BromoAMP-induced corticosteroids production by fetal adrenal cells in culture, probably by enhancing cholesterol availability to P450sce (Naaman et al, 1989). The synergistic effect of IGF-I and ACTH observed on corticosteroid production by cultured fetal adrenal cells suggests that IGF-I could be involved in the regulation of some steps of adrenal maturation which are ACTH-independent. Moreover, plasma IGFI concentrations are low in the ovine fetus up to G50; they then increase towards term when they become three-fold higher (Alexander et al, 1968; Gluckman and Butler, 1983; Handwerger et al, 1983). IGF-I could therefore be involved in the maintenance of specific functions of fetal adrenal cells in vivo, thus participating in increasing the steroidogenic 
potency of these cells before birth. However, IGF-II expression is much higher in fetal adrenals than IGF-I expression (Han et al, 1992). In addition, in the fetal ovine adrenal gland, IGF-I and IGF-II (mRNAs and proteins) have been co-localized with $3 \beta$-HSD (Han et al, 1992). Moreover, IGF-II expression is strongly diminished by ACTH or cortisol treatment in utero, suggesting that the prepartum increase of cortisol could be responsible for the decrease of IGF-II just before birth ( $\mathrm{Li}$ et al, 1993). Therefore, like IGF-I, IGF-II might also participate as an auto/paracrine factor of fetal adrenocortical development. Taken together, these results support the hypothesis that IGF-I and IGF-II modulate fetal adrenal differentiation.

\section{Negative effects}

\section{Role of A-II}

A-II is an octapeptide derived from angiotensinogen. Renin-angiotensin systems were found in various tissues such as in the adrenal gland (Pinet et al, 1992). Two types of receptors have been identified in various species (Bottari et al, 1993). In sheep, they are located in both the zona glomerulosa and fasciculata of adrenal glands (Viard et al, 1990). In ovine adrenal cells, A-II has no acute effect on steroidogenesis (Viard et al, 1990), unlike in bovine and human adrenal cells (Laird et al, 1991) where it increases cortisol production. A-II exerts a chronic effect on bovine (Rainey et al, 1991a), ovine adult (Bird et al, 1992) and fetal (Rainey et al, 1991b) adrenal cells. A-II is able to inhibit ACTHinduced expression of P450-C17 and 3 $\beta$-HSD (both on protein and mRNA levels). Moreover, in ovine fetal adrenal cells, A-II inhibits up to 70\% ACTH-induced cortisol production (Rainey et al, 1991b).

\section{Effect of TGF $\beta 1$}

Recently, TGF $\beta 1$ has been extensively studied and shown to be a potent inhibitor of adrenocortical differentiated functions whereas ACTH acts positively on these functions. Recent results have shown the existence of three types of TGF $\beta 1$ receptors of 65,85 and $200-300 \mathrm{kDa}$, corresponding, respectively, to types I, II and III in ovine, bovine and human adrenal cells (Lebrethon et al, 1994). TGF $\beta 1$ is highly expressed in the ovine fetal adrenal gland and could thereby be a physiological factor regulating negatively fetal adrenal function.

In vitro, TGF $\beta 1$ is able to inhibit cortisol production by ovine adult (Rainey et al, 1988) and fetal (Rainey et al, 1991b) adrenal cells. TGF $\beta 1$ exerts an effect on the ACTH-sensitive $\mathrm{AC}$ system at more than one level by decreasing both the number of ACTH receptors (Rainey et al, 1989) and the production of cAMP in response to cholera toxin and forskolin (Rainey et al, 1988). The inhibitory effect of TGF $\beta 1$ also occurs on steroidogenic activities. In the ovine adrenal gland, TGF $\beta 1$ inhibits mainly the expression and activity of P450-C17 (Rainey et al, 1988, 1991a; Perrin et al, 1990), and to a lesser extent 3 $\beta$-HSD (Naville et al, 1991a,b). In adult adrenal cells in culture, TGF $\beta 1$ inhibits cholesterol availability for steroidogenesis, as was previously observed for bovine adrenocortical cells (Hotta and Baird, 1986). In fetal and neonatal adrenocortical cells in culture (but not in adults), TGF $\beta 1$ inhibits P450scc activity and the relative amounts of the three corresponding proteins ( $\mathrm{P} 450 \mathrm{scc}$, adrenodoxin and adrenodoxin reductase) (Naaman-Répérant et al, 1996). ACTH is not able to reverse this inhibition either in fetuses or in newborns even after a 6 day treatment (our unpublished results). In addition, both concentrations of TGF $\beta 1$ encoding mRNAs and of immunoreactive TGF $\beta$ 1-like proteins are higher in fetal than in neonatal adrenal glands (NaamanRépérant et al, 1996). The amounts of TGF $\beta 1$ encoding mRNAs and corresponding proteins in 120-day-old fetal adrenal cells decrease during the first 2 days of culture. This decrease occurs simultaneously with the 'spontaneous increase' of P450scc activity in the same cells 


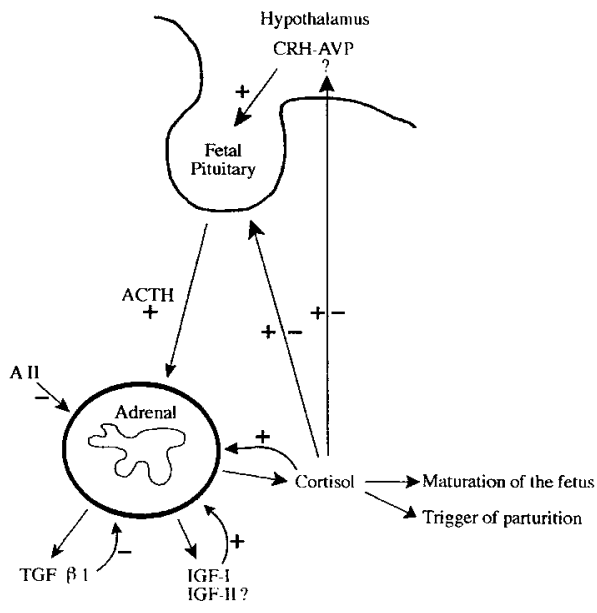

Fig 3. Regulation of the steroidogenic activity of the fetal ovine adrenal gland. + positive effect; - negative effect. A II : angiotensin II; ACTH : adrenocorticotropic hormone; CRH-AVP: corticotropinreleasing hormone-arginine vasopressin; IGF-I and II: insulin-like growth factors I and II; TGF $\beta 1$ : transforming growth factor $\beta 1$.

during the first 2 days of culture. Therefore, and considering TGF $\beta 1$ inhibition on adrenal maturation and steroidogenesis in vitro, it is tempting to speculate that TGF $\beta 1$ also plays an important role in vivo.

\section{CONCLUSION}

During gestation, there is a multifactorial regulation of the adrenal which involves both the hypothalamo-pituitary corticotrope axis and local regulations which modulate the action of ACTH. At late gestation, fetal adrenal maturation leads to an increased production of cortisol. During this period, there is a positive regulation loop between the effect of ACTH on the fetal adrenal and the action of glucocorticoids on the secretion of bioactive ACTH. Fetal glucocorticoids have not only an effect on the hypothalamo-pituitary axis, but exert also a local auto/paracrine effect on their own synthesis. These local regulations are modu- lated both by A-II (Rainey et al, 1991b) and growth factors such as IGF-I, IGF-II (Han et al, 1992; Li et al, 1993) and TGFß1 (Naaman-Répérant et al, 1996) which are present both in the blood and in the fetal adrenal. AII and TGF $\beta 1$ exert a negative effect on adrenal steroidogenesis whereas IGF-I stimulates it. We therefore hypothetize that TGF $\beta 1$ would prevent an early increase in fetal corticosteroids leading to premature parturition, whereas IGF-I participates in the enhancement of fetal adrenal activity leading to the prepartum increase in cortisol. These regulations have been summarized in figure 3 .

Finally, several factors appear able to regulate fetal adrenal steroidogenesis. Additional experiments are now needed to determine the relationships existing between these various factors that are responsible for the development of fetal adrenal steroidogenic ability during the last third of gestation. It is also important to study the regulation of these factors during this same period.

\section{REFERENCES}

Alexander DP, Britton VHT, Nixon J, Parker RA (1968) Steroid secretion by the adrenal gland of fetal and neonatal sheep. I Endocrinol 40, 1-13

Antolovich GA, Perry RA, Trahair JF, Silver M, Robinson PM (1989) The development of corticotrophs in the fetal sheep pars distalis: the effect of adrenalectomy or cortisol infusion. Endocrinology 124, 1333-1339

Antolovich GC, McMillen IC, Robinson PM, Silver M, Young IR, Perry RA (1991) The effect of hypothalamo-pituitary disconnection (HPD) on the functional and morphologic development of the pituitary-adrenal axis in the fetal sheep in the last third of gestation. Neuroendocrinology 54, 254-261

Ballard DL, Kitterman JA, Bland RD, Clyman RI, Gluckman PD, Platzker ACG, Kaplan SL, Grumbach MM (1982) Ontogeny and regulation of corticosteroid binding capacity in plasma of fetal and newborn lambs. Endocrinology 110, 359-366

Bégeot M, Langlois D, Spiegel AM, Saez JM (1991) Regulation of guanine nucleotide binding regula- 
tory proteins in cultured adrenal cells by ACTH and AII. Endocrinology 128, 3162-3168

Berdusco ETM, Yang K, Hammond GL, Challis JRG (1995) CBG production by hepatic and extrahepatic sites in the ovine fetus; effects of CBG on glucocorticoid negative feedback on pituitary cells in vitro. J Endocrinol 146, 121-130

Bird IM, Magness RR, Mason JI, Rainey WE (1992) AII acts via the type 1 receptor to inhibit $[17 \alpha-$ hydroxylase cytochrome $\mathrm{P} 450$ expression in ovine adrenocortical cells. Endocrinology 130,3113-3121

Boshier DP, Holloway H (1989) Morphometric analyses of adrenal gland growth in fetal and neonatal sheep. I. The adrenal cortex. J Anat 167, 1-14

Bottari SP, de Gasparo M, Steckelings UM, Levens NR (1993) AII receptor subtypes: characterization, signalling mechanisms, and possible physiological implications. Front Neuroendocrinol 14, 123-171

Brieu V, Durand PH (1987) Changes in the ratio of bioactive to immunoreactive ACTH-like activity released by pituitary cells from ovine fetuses and lambs. Endocrinology 120, 936-940

Brieu V, Durand PH (1989) ACTH released by pituitary cells from ovine fetuses and lambs: polymorphism and biological activity. Neuroendocrinology 49, 300-308

Brieu V, Tonon MC, Lutz-Bucher B, Durand PH (1989) CRF-like immunoreactivity, AVP-like immunoreactivity and ACTH-like bioactivity in hypothalamic tissue from fetal and neonatal sheep. Neuroendocrinol 49, 164-168

Brown EH, Coghlan JP, Hardy KJ, Wintour EM (1978) Aldosterone, corticosterone, cortisol, 11 deoxycortisol and 11 deoxy corticosterone concentrations in the blood of chronically cannulated ovine fetuses: effect of ACTH. Acta Endocrinol (Copenh) 88, 364-374

Cabalum TC, Oakes GK, Jansen CAM, Yu HK, Hammer T, Buster JE, Nathanielsz PW (1982) Induction of parturition in sheep by low dose intrafetal infusion of synthetic ACTH1-24 at 120-130 days of gestation. Endocrinology 110, 1408-1415

Carr GA, Jacobs RA, Young IR, Schwartz J, White A, Crosby S, Thorburn GD (1995) Development of ACTH1-39 and precursor peptide secretory responses in the fetal sheep during the last third of gestation. Endocrinology 136, 5020-5027

Cathiard AM, Crozat A, Durand P, Saez, JM (1985) In vitro spontaneous and adrenocorticotropindependent maturation of the steroidogenic pathway of the ovine fetal cells. Endocrinology 116 , 585-590
Challis JRG, Lye SJ (1986) Parturition. Oxford Rev Reprod Biol 8, 61-129

Challis JRG, Brooks AN (1989) Maturation and activation of hypothalamus-pituitary adrenal function in fetal sheep. Endocr Rev 10, 182-204

Challis JRG, Jones CT, Robinson JS, Thorburn GD (1977) Development of fetal pituitary-adrenal function. J Steroid Biochem 8, 471-478

Cone RD, Mountjoy KG (1993) Molecular genetics of the ACTH and MSH receptors. Trends Endocrinol Metabol 4, 242-247

Darbeida H, Durand PH (1987) Glucocorticoid enhancement of ACTH-induced CAMP production by cultured ovine adrenocortical cells. Endocrinology 121, 1051-1055

Darbeida H, Durand PH (1990) Mechanism of glucocorticoid enhancement of the responsiveness of ovine adrenocortical cells to ACTH. Biochem Biophys Res Commun 166, 1183-1191

Darbeida H, Naaman E, Durand PH (1987) Glucocorticoid induction of the maturation of ovine fetal adrenal cells. Biochem Biophys Res Commun 145, 999-1005

Durand PH (1979) ACTH receptor levels in lamb adrenals at late gestation and early neonatal stages. Biol Reprod 20, 837-846

Durand PH (1987) Développement de l'axe hypophyso-surrénalien au cours de la vie fotale : modalités et régulations. Ann Endocrinol (Paris) 48, 301-310

Durand PH (1992) Regulation of the development of the ovine fetal adrenal function. In: Cellular and Molecular Biology of the Adrenal Cortex (JM Saez, AC Brownie, A Capponi, EM Chambaz, F Montero, eds), Colloque INSERM, vol 222, 247-257

Durand PH, Bosc M, Nicolle A (1978) Croissance des surrénales de fotus ovin en fin de gestation : évolution de l'ADN et des protéines membranaires. CR Acad Sci Paris 287, 297-300

Durand PH, Bosc M, Locatelli A (1980) Adrenal maturation of the sheep fetus during late pregnancy. Reprod Nutr Dev 20, 339-347

Durand PH, Cathiard AM, Locatelli A, Dazord A, Saez JM (1981a) Spontaneous and adrenocorticotropininduced maturation of the responsiveness of ovine fetal adrenal cells to in vitro stimulation by ACTH and choleratoxin. Endocrinology 109, 2117-2123

Durand PH, Cathiard AM, Morera AM, Dazord A, Saez JM (1981b) Maturation of adrenocorticotropin-sensitive adenylate cyclase of ovine fetal 
adrenal during late pregnancy. Endocrinology 108, 2114-2118

Durand PH, Locatelli A, Cathiard AM, Dazord A, Saez JM (1981c) ACTH induction of the maturation of ACTH-sensitive adenylate cyclase system in the ovine fetal adrenal. I Steroid Biochem 15, 445-448

Durand PH, Cathiard AM, Locatelli A, Saez JM (1982a) Modification of the steroidogenic pathway during spontaneous and adrenocorticotropininduced maturation of the ovine fetal adrenal. Endocrinology 110,500-505

Durand PH, Cathiard AM, Locatelli A, Saez JM (1982b) Ontogenèse de la fonction corticosurrénalienne dans l'espèce ovine. Colloques de I'INSERM 109, 189-218

Durand PH, Cathiard AM, Saez JM (1984) In vitro maturation of the steroidogenic capacity of ovine fetal and neonatal adrenal cells. Endocrinology 114, 1128-1134

Durand PH, Cathiard AM, Saez JM (1985a) Involvement of the regulatory proteins (Ns) in the maturation of $\mathrm{ACTH}$-sensitive adenylate cyclase of ovine fetal adrenal during late gestation. Mol Cell Endocrinol 39, 145-150

Durand PH, Cathiard AM, Saez JM (1985b) Maturation of the ovine fetal adrenal gland: in vivo and in vitro studies. In: The Endocrine Physiology of Pregnancy and the Peripartal Period (RB Jaffe, S Dell'Acqua, eds), Serono symposium, Raven Press, New York, USA 21, 31-52

Durand PH, Cathiard AM, Dacheux F, Naaman E, Saez JM (1986) In vitro stimulation and inhibition of adrenocorticotropin release by pituitary cells from ovine fetuses and lambs. Endocrinology 118, 1387-1394

Durand PH, Cathiard AM, Naaman E, Brieu V, Saez JM (1987) The influence of plasma lipoproteins on steroidogenesis of cultured ovine fetal and neonatal adrenal cells. J Steroid Biochem 26, 425-431

Eipper BA, Mains RE (1980) Structure and function of proopiomelano-cortin/endorphin and related peptides. Endocr Rev 1, 247-262

Estivariz FE, Iturriza F, McLean C, Hope J, Lowry PJ (1982) Stimulation of adrenal mitogenesis by $\mathrm{N}$ terminal proopiomelanocortin peptides. Nature $297,419-422$

Féger J, Féger J (1993) In: Pharmacologie moléculaire (Y Landry, JP Gies, eds), Arnette, Paris, France, 176, 191

Feige JJ, Baird A (1991) Growth factor regulation of adrenal cortex growth and function. Prog Growth Factor Res 3, 103-113
Gluckman PD, Butler JH (1983) Parturition-related changes in IGF-I and II in the perinatal lamb. J Endocrinol 99, 223-232

Gospodarowicz D, Ill CR, Hornsby PJ, Gill GN (1977) Control of bovine cell proliferation by FGF. Lack of effect of EGF. Endocrinology 100, 1080-1089

Han VKM, Lü F, Bassett N, Yang K, Delhantry PJD, Challis JRG (1992) IGF-II mRNA is expressed in steroidogenic cells of the developing ovine adrenal gland: evidence for an auto/paracrine role for IGFII. Endocrinology 131, 3100-3109

Handwerger S, D'Ercole AJ, Underwood LE, Gluckman P, Liggins GC (1983) Serum somatomedin C concentrations in the fetal sheep increase markedly during gestation. $J$ Endocrinol 96, 269-271

Hargrave BY, Rose JC (1986) By 95 days of gestation CRF increases plasma ACTH and cortisol in ovine fetuses. Am J Physiol Endocrinol Metab 13 , E422-E427

Hennessy DP, Hardy KG, Quigley ME, Wintour EM, Yen SSC (1982) Immunoreactive $\beta$-endorphin/ lipotropin in the chronically cannulated ovine fetuses: response to bilateral fotal adrenalectomy. Acta Endocrinol (Copenh) 99, 612-618

Hornsby PJ, Gill GN (1977) Hormonal control of cell proliferation, desensitization to ACTH and interaction between ACTH and FGF in bovine adrenocortical cell cultures. $J$ Clin Invest $60,342-352$

Hotta M, Baird A (1986) Differential effects of TGF $\beta$ on the growth and function of adrenocortical cells in vitro. Proc Natl Acad Sci USA 83, 7795-7799

Jacobs RA, Young IR, Hollingworth SA, Thorburn GD (1994) Chronic administration of low doses of ACTH to hypophysectomized fetal sheep leads to normal term labor. Endocrinology 134, 1389-1394

Jones CT (1979) Normal fluctuations in the concentration of corticosteroids and ACTH in the plasma of fetal and pregnant sheep. Horm Metab Res 11 , 237-241

Jones C'T, Robuck MM (1980) ACTH peptides and the development of the fetal adrenal. $J$ Steroid Biochem 12, 77-82

Jones CT, Boddy K, Robinson JS (1977) Changes in the concentration of ACTH and corticosteroid in the plasma of fetal sheep in the later half of pregnancy and during labor. $J$ Endocrinol $72,293-300$

Jones CT, Johnson P, Kendall JZ, Ritchie JWK, Thorburn GD (1978a) Induction of premature parturition in sheep: ACTH and corticosteroid changes during infusion of synacthen into the fetus. Acta Endocrinol (Copenh) 87, 192-202 
Jones CT, Kendall JZ, Ritchie JWK, Robinson JS, Thorburn GD (1978b) ACTH and corticosteroid changes during dexamethasone infusion to intact and hypophysectomized fetuses. Acta Endocrinol (Copenh) 87, 203-211

Laird SM, Hinson JP, Vinson GP, Mallick N, Kapas S, Teja R (1991) Control for steroidogenesis by the calcium messenger system in human adrenocortical cells. J Mol Endocrinol 6, 45-51

Lebrethon MC, Jaillard C, Naville D, Begeot M, Saez JM (1994) Effects of TGF $\beta 1$ on human adrenocortical fasciculata-reticularis cell differentiated functions. J Clin Endocrinol Metab 79, 1033-1039

Levidiotis M, Oldfield B, Wintour ME (1987) CRF and AVP fibre projections to the median eminence of fetal sheep. Neuroendocrinology 46, 453-456

Li J, Saundres JC, Gilmour RS, Silver M, Fowden AL (1993) Insulin-like growth factor-II mRNA expression in fetal tissues of the sheep during late gestation: effects of cortisol. Endocrinology 132, 20832089

Liggins GC (1968) Premature parturition after infusion of corticotrophin or cortisol into fetal lambs. J Endocrinol 42, 323-329

Liggins GC (1976) Adrenocortical maturational events in the fetus. Am J Obstet Gynecol 126, 931-941

Liggins GC (1994) The role of cortisol in preparing the fetus for birth. Reprod Fertil Dev 6, 141-150

Liggins GC, Fairclough RJ, Grieves JA, Kendall JZ, Knox BS (1973) The mechanism of initiation of parturition in the ewe. Recent Prog Horm Res 29, 111-150

Long JA (1975) Zonation of the mammalian adrenal cortex. In: Handbook of Physiology, section 7, vol VI: Adrenal Gland (H Blasko, G Sayers, AD Smith, eds), American Physological Society, Washington, DC, USA, 13-24

Loose DS, Do YS, Chen TL, Feldman D (1980) Demonstration of glucocorticoid receptors in the adrenal cortex: evidence for a direct dexamethasone suppressive effect on the rat adrenal gland. Endocrinology 107, 137-146

Magyar DM, Fridshal D, Elsner CW, Glatz T, Elliot J, Klein AM, Lowe KC, Buster JE, Nathanielsz PW (1980) Time trend analysis of plasma cortisol concentrations in the fetal sheep in relation to parturition. Endocrinology 107, 155-159

McDonald TJ, Nathanielsz PW (1991) Bilateral destruction of the fetal paraventricular nuclei prolongs gestation in sheep. Am J Obstet Gynecol 165, 764-770
Mulvogue HM, McMillen IC, Robinson PM, Perry RA (1986) Immunocytochemical localization of pro $\gamma$-MSH, $\gamma$-MSH, ACTH and $\beta$-endorphin $/ \beta$ lipotropin in the fetal sheep pituitary: an ontogenic study. J Dev Physiol 8, 355-368

Naaman E, Chatelain P, Saez JM, Durand PH (1989) In vitro effect of insulin and insulin-like growth factor-I on cell multiplication and adrenocorticotropin responsiveness of fetal adrenal cells. Biol Reprod 40, 570-577

Naaman-Répérant E, Cathiard AM, Durand PH (1992) Ontogenesis of cholesterol side-chain cleavage activity in the ovine adrenal gland. J Steroid Biochem Mol Biol 43, 301-310

Naaman-Répérant E, Hales DB, Durand PH (1996) Effect of TGF $\beta 1$ on the cholesterol side-chain cleavage system in the adrenal gland of sheep fetuses and newborns. Endocrinology 137, 886892

Nathanielsz PW (1978) Endocrine mechanism of parturition. Annu Rev Physiol 40, 411-415

Nathanielsz PW, Comline RS, Silver M, Paisey RD (1972) Cortisol metabolism in the fetal and neonatal sheep. I Reprod Fertil 16, 39-59

Nathanielsz PW, Jack PMB, Krane EJ, Thomas AL, Ratter S, Rees LH (1977) The role and regulation of corticotropin in the fetal sheep. In: The Fetus and birth. Ciba Foundation symposium, Excerpta Medica, Amsterdam, The Netherlands, 47, 73-98

Naville D, Rainey WE, Mason JI (1991a) Corticotropin regulation of 3- $\beta$-hydroxysteroid dehydrogenase/ $\Delta 5-4$-isomerase in ovine adrenocortical cells: inhibition by transforming growth factor $\beta$. Mol Cell Endocrinol 75, 257-263

Naville D, Rainey WE, Milwich L, Mason JI (1991b) Regulation of $3 \beta$-hydroxysteroid dehydrogenase/ $\Delta 5-4$-isomerase expression by adrenocorticotropin in bovine adrenocortical cells. Endocrinology $128,139-144$

Penhoat A, Jaillard C, Saez JM (1989) Synergistic effects of corticotropin and IGF-I on corticotropin receptors and corticotropin responsiveness in cultured bovine adrenocortical cells. Biochem Biophys Res Commun 165, 355-359

Perrin A, Pascal O, Defaye G, Feige JJ, Chambaz EM (1990) TGFB1 is a negative regulator of steroid $17 \alpha$-hydroxylase expression in bovine adrenocortical cells. Endocrinology 128, 357-362

Picard-Hagen N, Darbeida H, Durand PH (1995) Glucocorticoid induction of the maturation of ovine fetal adrenal cells. Biochem Biophys Res Commun 145, 999-1005 
Picard-Hagen N, Penhoat A, Hue D, Jaillard C, Durand PH (1996) Glucocorticoids enhance the ACTH receptor mRNA levels in ovine adrenocortical cells: evidence for a transcriptional effect (in press)

Pinet F, Racz K, Gasc JM, Guyene TT, Corvol P (1992) Local adrenal renin-angiotensin system. In: Cellular and Molecular Biology of the Adrenal Cortex (JM Saez, AC Brownie, A Capponi, EM Chambaz, F Mantero, eds), Colloque INSERM 222

Rainey WE, Viard I, Mason JI, Cochet C, Chambaz EM, Saez JM (1988) Effects of transforming growth factor beta on ovine adrenocortical cells. Mol Cell Endocrinol 60, 189-198

Rainey WE, Viard I, Saez JM (1989) TGF $\beta$ treatment decreases ACTH receptors on ovine adrenocortical cells. J Biol Chem 264, 21474-21477

Rainey WE, Naville D, Mason JI (1991a) Regulation of $3 \beta$-HSD in adrenocortical cells: effects of AII and TGF 3 . Endocr Res Commun 17, 281-296

Rainey WE, Oka K, Magness RR, Mason JI (1991b) Ovine fetal adrenal synthesis of cortisol: regulation by ACTH, AII and TGF $\beta$. Endocrinology 129, 1784-1790

Rees LH, Jack PMB, Thomas A, Nathanielsz PW (1975) Role of fetal ACTH during parturition in sheep. Nature 253, 274-275

Robinson PM, Rowe EJ, Wintour EM (1979) The histogenesis of the adrenal cortex in the foetal sheep. Acta Endocrinol (Copenh) 91, 134-149

Saez JM, Durand P, Cathiard AM (1984) Ontogeny of the ACTH receptor, adenylate cyclase and steroidogenesis in adrenal. Mol Cell Endocrinol 38, 93-102

Saez JM, Bégeot M, Durand PH (1989) Récepteurs de l'ACTH. Ann Endocrinol (Paris) 50, 409-417

Sara VR, Hall K (1990) Insulin-growth factors and their binding proteins. Physiol Rev 707, 591-614

Silman RE, Holland D, Chard T, Lowry PJ, Hope J, Rees LH, Thomas A, Nathanielsz PW (1979) ACTH related peptides in adult and fetal sheep pituitary glands. $J$ Endocrinol $123,371-377$

Simpson ER, Waterman MR (1988) Regulation of the synthesis of steroidogenic enzymes in adrenal cortical cells by ACTH. Annu Rev Physiol 50, 427-440

Sundell N, Serenius FS, Barthe P, Friedman Z, Kanarek KS, Escabo MB, Orth DN, Stahlman MT (1975) The effect of EGF on fetal lamb lung maturation. Pediatr Res 9, 371 (abstr 687)

Tangalakis K, Coghlan JP, Connell J, Crawford R, Darling P, Hammond VE, Haralambidis J, Penschow J, Wintour EM (1989) Tissue distribution and levels of gene expression of three steroid hydroxylases in ovine fetal adrenal glands. Acta Endocrinol (Copenh) 120, 225-232

Tangalakis K, Coghlan JP, Crawford R, Hammond VE, Wintour EM (1990) Steroid hydroxylase gene expression in the ovine fetal adrenal gland following ACTH infusion. Acta Endocrinol (Copenh) 123, 371-377

Tangalakis K, Roberts FE, Wintour EM (1992) The time course of ACTH stimulation of cortisol synthesized by the immature ovine fetal adrenal gland. I Steroid Biochem Mol Biol 42, 527-532

Thomas SJ, Wilson DW, Pierrepoint CG, Lameron EMD, Griffiths H (1976) Measurement of cortisol, cortisone, 11-deoxycortisol and corticosterone in fetal sheep plasma during the perinatal period. $J$ Endocrinol 68, 181-189

Viard I, Rainey WE, Capponi AM, Bégeot M, Saez JM (1990) Ovine adrenal fasciculata cells contain AII receptors coupled to intracellular effectors but are resistant to the steroidogenic effects of this hormone. Endocrinology 127, 2071-2078

Webb PD (1980) Development of the adrenal cortex in the fetal sheep: an ultrastructural study. $J$ Dev Phys 2, 161-181

Wintour EM, Brown EH, Denton DA, Hardy KJ, McDougall JG, Oddie CJ, Whipp GT (1975) The ontogeny and regulation of corticosteroid secretion by the ovine fœtal adrenal. Acta Endocrinol (Copenh) 79, 301-316

Wintour EM, Coghlan JP, Hardy KG, Hennessy DP, Lingwood BE, Scoggins BA (1980) Adrenal corticosteroids and immunoreactive ACTH in chronically cannulated ovine fetuses with bilateral adrenalectomy. Acta Endocrinol (Copenh) 95, 546552

Wintour EM, Crawford R, McFarlane A, Moritz K, Tangalakis K (1995) Regulation and function of the fetal adrenal gland in sheep. Endocr Res Commun 21, 81-89

Wood CE, Rudolph AM (1983) Negative feedback regulation of ACTH secretion by cortisol in ovine fetuses. Endocrinology 112, 1930-1936

Yang K, Jones SA, Challis JRG (1990) Changes in glucocorticoid receptor number in the hypothalamus and pituitary of the sheep fetus with gestational age and adrenocortricotropin treatment. Endocrinology 126, 11-17

Yang K, Matthews SG, Challis JRG (1995) Developmental and glucocorticoid regulation of pituitary 11ß-hydroxysteroid dehydrogenase 1 gene expression in the ovine fetus and lambs. J Mol Endocrinol 14, 109-116 